\title{
Identification of Chemical Constituents and Evaluation of the Antibacterial Activity of Methanol Extract and Fractions of the Leaf of Melanthera scandens (Schum. et Thonn.) Roberty
}

\author{
Julius K. Adesanwo ${ }^{1 *}$, Ifeoluwa S. Ajayi ${ }^{1}$, Olukayode S. Ajayi ${ }^{1}$, \\ Oluwatoyin A. Igbeneghu ${ }^{2}$ and Armando G. McDonald ${ }^{3}$ \\ ${ }^{1}$ Department of Chemistry, Faculty of Science, Obafemi Awolowo University, Ile-Ife, Nigeria; ${ }^{2}$ Faculty of Pharmacy, Obafemi Awolowo \\ University, Ile-Ife, Nigeria; ${ }^{3}$ Department of Forest, Rangeland and Fire Sciences, University of Idaho, Moscow, 83844-1132, USA
}

\begin{abstract}
Background and objectives: The chemical composition of Melanthera scandens (MS) methanol (MeOH) extract is yet to be fully comprehended. Chemical composition of a plant extract is closely related to the biological activity of the plant material, in phytomedicine. In this study, chemical analyses of MS extracts were carried out with the aim of identifying the organic chemical constituents.
\end{abstract}

Methods: Powdered MS leaf was soxhlet extracted with dichloromethane and $\mathrm{MeOH}$. The solvent extracts were analyzed using electrospray ionization-mass spectrometer and GC-MS (fatty acid methyl ester and trimethylsilyl derivatives). Fresh MS leaves were cold extracted with $\mathrm{MeOH}$ for biological studies and isolation of compounds. The $\mathrm{MeOH}$ extract was screened for phytochemical constituents and partitioned with $n$-hexane, ethyl acetate (EtOAc) and $n$-butanol to give the respective fractions. The $n$-hexane fraction was examined for volatile constituents using gas chromatography-mass spectrometry. Antibacterial study of $n$-hexane, EtOAc, butanol fractions and crude $\mathrm{MeOH}$ extract was undertaken; extract and fractions were screened against $E$. coli, $P$. aeruginosa, $B$. subtilis, $B$. cerus and $S$. aureus. The minimum inhibitory concentration and minimum bactericidal concentration of the EtOAc fraction (the most active) were determined using the macrobroth dilution method, and the fraction was subjected to column fractionation. Eluents were monitored by thin-layer chromatography. The combined fractions that exhibited antibacterial activity were further purified to obtain isolates which were characterized by spectroscopic techniques - nuclear magnetic reso-

Keywords: Melanthera scandens; Antibacterial study; Asteraceae; Isolation. Abbreviations: AoOe, 3 $\beta$-acetoxyolean-12-ene; ATCC, American Type Culture Collection; ${ }^{13} \mathrm{CNMR}$, carbon 13 nuclear magnetic resonance spectroscopy; $\mathrm{CDCl}_{3}$, deuterated chloroform; $\mathrm{CH}_{3} \mathrm{OH}$, methanol; DCM, dichloromethane; EFAs, essential fatty acids; ESI-MS, electrospray ionization-mass spectrometer; EtOAc, ethyl acetate; FAME, fatty acid methyl ester; FAs, fatty acids; FTIR, Fourier transform infrared; GC-MS, gas chromatography-mass spectrometry; Gram +ve, Gram positive; Gram -ve, Gram negative; GrGOa, 3-O- $\beta$-D-glucoronopyranosyl-28-O- $\beta$-Dglucopyranosyl-oleanolate; GrOA, 3-O- $\beta$-D-glucuronopyranosyl-oleanolic acid; GXGrGOa, 3-O-\{[ß- D-glucopyranosyl $(1 \rightarrow 2)]$ [ $\beta$-D-xylopyranosyl $(1 \rightarrow 4)] \beta$-Dglucuronopyranosyl $\}$-28-O- $\beta$-D-glucopyranosyl-oleanolate; ${ }^{1}$ HNMR, proton nuclear magnetic resonance spectroscopy; HPLC, high-performance liquid chromatography; IS, internal standard; MIC, minimal inhibitory concentration; MS, Melanthera scandens; NCTC, National Collection of Type Culture; NIST, National Institute of Standard and Technology; ppm, parts per million; RGUe, $3 \beta-O-[\alpha$ rhamnopyranosyl- $(1 \rightarrow 6)$ $\beta$-glucopyranosyl- $(1 \rightarrow 3)$-ursan-12-ene; TLC, thin-layer chromatography; TMS, trimethylsilyl; XGrGOa, 3-O-[ $\beta$-D-xylopyranosyl $(1 \rightarrow 4) \beta$-D-glucuronopyranosyl]28 -O- $\beta$-D-glucopyranosyl-oleanolate; XGrOA, 3-O-[ $\beta$-D-xylopyranosyl $(1 \rightarrow 4) \beta$-Dglucuronopyranosyl]-oleanolic acid.

Received: June 28, 2019; Revised: August 26, 2019; Accepted: September 05, 2019 *Correspondence to: Julius K. Adesanwo, Department of Chemistry, Faculty of Science, Obafemi Awolowo University, Ile-Ife, Nigeria. E-mail: adesanwojk@yahoo.com How to cite this article: Adesanwo JK, Ajayi IS, Ajayi OS, Igbeneghu OA, McDonald AG. Identification of Chemical Constituents and Evaluation of the Antibacterial Activity of Methanol Extract and Fractions of the Leaf of Melanthera scandens (Schum. et Thonn.) Roberty. J Explor Res Pharmacol 2019;4(3):31-40. doi: 10.14218/JERP.2019.00007. nance, Fourier transform infrared, gas chromatography-mass spectrometry (fatty acid methyl ester and trimethylsilyl) and electrospray ionization-mass spectrometer.

Results: Phytochemical screening of MS extracts showed the presence of alkaloids, tannins, cardiac glycoside, saponins and steroid, while flavonoid was not detected. The $\mathrm{n}$-hexane fraction, EtOAc fraction, and crude $\mathrm{MeOH}$ extract inhibited the growth of Bacillus species, while the butanol fraction did not display any activity against the tested microbes. The EtOAc fraction showed the greatest activity. Gas chromatography-mass spectrometry analysis of the $n$-hexane fraction identified 14 compounds, among which phytol was of highest percentage composition. Ten different compounds were identified in the dichloromethane extract, consisting mainly of oleanane and ursolane derivatives. Electrospray ionization-mass spectrom- 
eter analysis tentatively identified 5 triterpenoid glycosides.

Conclusions: The MEOH extract and its fractions, except the n-butanol fraction, inhibited the activity of Bacillus species considerably, from among the tested microbes, to varying degrees. A total of 54 different bioactive chemical compounds were identified in the leaf extract of MS. These compounds contribute to its biological activities, including antibacterial, thereby justifying its use in ethno-medicine to manage diseases caused by pathogenic microorganisms.

\section{Introduction}

Melanthera scandens (MS) belongs to the plant family Asteraceae and is found mostly in tropical regions, including Nigeria, Mexico, Central America, South America, and Sub-Saharan Africa. ${ }^{1,2}$ The common names are Aboyunrinyun (Yoruba) and vine (English).

MS is a scrambling or scandent herb of waste thickets, cultivation edges and forest margins, commonly dispersed in the forested areas of the region. The plant is often confused with Aspilia africana and has almost the same uses. Herbalists use the juice of the leaves to stop dysentery. It is also used for the treatment of skin infections, gastroenteritis, and stomach ache, and as a diuretic and treatment for hypertensive activities. It is used against piles, diarrhea and hemorrhoids. ${ }^{3}$ Infusion or decoction of the leaves is used as an emetic, and cough and febrile headache medicine. ${ }^{4}$ In Côte d'Ivoire, the leaves are used as a purgative and an antidote against poisoning. In Nigeria, pulped, decocted or macerated leaves are used as hemostatic preparations, applied to cuts and wounds to promote healing and curb inflammation. ${ }^{2}$ Finally, the aerial part of MS is used as feed stock for rabbits. ${ }^{5}$

Compounds in MS that have been previously reported include oleanolic acid (OA), 3-O- $\beta$-D-glucuronopyranosyl-oleanolic acid $(\mathrm{GrOA}), 3-\mathrm{O}-[\beta-\mathrm{D}$-xylopyranosyl $(1 \rightarrow 4) \beta$-D-glucuronopyranosyl]oleanolic acid (XGrOA), 3-O- $\{[\beta-D-$ glucopyranosyl $(1 \rightarrow 2)]$ $[\beta$-D-xylopyranosyl $(1 \rightarrow 4)] \beta$-D-glucuronopyranosyl $\}$-oleanolic acid (GXGrOA), 3-O- $\beta$-D-glucuronopyranosyl-28-O- $\beta$-Dglucopyranosyl-oleanolate (GrGOa), 3-O- $\{[\beta-\mathrm{D}$-glucopyranosyl $(1 \rightarrow 2)$ ] [ $\beta$-D-xylopyranosyl $(1 \rightarrow 4)] \beta$-D-glucuronopyranosyl $\}$ $28-\mathrm{O}-\beta$-D-glucopyranosyl-oleanolate (GXGrGOa) and 3-O-[ $\beta$ $\mathrm{D}$-xylopyranosyl $(1 \rightarrow 4) \beta$-D-glucuronopyranosyl]-28-O- $\beta$-Dglucopyranosyl-oleanolate ${ }^{6}$ (XGrGOa).

The current study aimed to investigate the organic chemical constituents of MS and bioactive fractionation of MS extract in order to identify phytochemicals responsible for activity.

Materials and methods

\section{Plant materials}

The leaves of MS were collected from Ogo-Oluwa farm, Ido-Ijesa, Ilesa, Osun State, Nigeria. The plant was identified and authenticated (voucher specimen number: FPI/2084) by Mr. I. J. Ogunlowo, Pharmacy Herbarium, Ile-Ife, Nigeria.

\section{Preparation of the extracts}

Extraction for chemical analysis

The MS leaves were dried at $60^{\circ} \mathrm{C}$ for $48 \mathrm{~h}$ and milled to $1 \mathrm{~mm}$ particle size. Moisture content was determined in duplicate before extraction. The plant material was soxhlet extracted, first with dichloromethane (DCM) $(150 \mathrm{~mL})$ for $24 \mathrm{~h}$ and then with methanol $(\mathrm{MeOH})(150 \mathrm{~mL})$ for $48 \mathrm{~h}$. The extracts were concentrated to dryness using a rotary evaporator. Extractives yields were $2.71 \%$ for DCM and $4.48 \%$ for $\mathrm{MeOH}$.

Large-scale extraction for biological assay and compound isolation

The MS leaves were air dried and ground into fine powder. The powdered MS leaf $(2.5 \mathrm{~kg})$ was extracted (3 times) by steeping in $\mathrm{MeOH}(10 \mathrm{~L})$ for $24 \mathrm{~h}$ and then filtered. The extract was concentrated to dryness to afford $150 \mathrm{~g}(6 \%$ yield $)$ of crude extract. The crude $\mathrm{MeOH}$ extract $(100 \mathrm{~g})$ was dissolved in water $(500 \mathrm{~mL})$, partitioned sequentially with $n$-hexane $(3 \times 200 \mathrm{~mL})$, ethyl acetate $($ EtOAc) $(3 \times 200 \mathrm{~mL})$ and n-butanol $(3 \times 200 \mathrm{~mL})$ using a separating funnel to give the respective solvent fractions.

\section{Phytochemical screening of the MS MeOH extract}

Qualitative phytochemical screening was carried out by standard procedure, based on earlier reports and described below. ${ }^{5,7,8}$

\section{Test for flavonoids}

The MS MeOH extract $(0.05 \mathrm{~g})$ was dissolved in water $(5.0 \mathrm{~mL})$ and filtered. To the filtrate $(1.0 \mathrm{~mL})$, a few drops of ethanolic $\mathrm{KOH}$ solution were added. The resulting solution was examined for formation of suspension, cloudiness or precipitation characteristic of flavonoids.

\section{Test for tannins}

The MS MeOH extract $(0.05 \mathrm{~g})$ was dissolved in water $(20 \mathrm{~mL})$ and then filtered. A few drops $(2-3)$ of $0.1 \%$ ferric chloride in glacial acetic acid solution were added to the filtrate. The mixture was examined for the formation of brownish green or blue-back precipitate characteristic of tannins.

\section{Test for alkaloids}

The MS extract $(50 \mathrm{mg}$ ) was placed into three separate test tubes, with $10 \mathrm{~mL}$ of $10 \%(\mathrm{v} / \mathrm{v}) \mathrm{HCl}$ added, boiled, and filtered. To each filtrate, separately, $1.0 \mathrm{~mL}$ of Mayer's reagent, Wagner's reagent, and Drangendorff reagent were added. The formation of a cream precipitate (with Mayer's reagent), an orange precipitate (with Dragendorff's reagent), or a reddish brown precipitate (with Wagner's reagent) was regarded as indicating positivity for the pres- 
ence of alkaloids. An equal volume of $10 \%(\mathrm{v} / \mathrm{v}) \mathrm{HCl}$ was used as a parallel control.

\section{Test for saponins (frothing test)}

The $\mathrm{MeOH}$ extract $(50 \mathrm{mg})$ in a tube was suspended in water $(2.0$ $\mathrm{mL}$ ) and shaken vigorously. The tube was then warmed to $70^{\circ} \mathrm{C}$ and shaken vigorously again. The appearance and persistence of frothing before and after warming indicated the presence of saponin.

\section{Test for steroids}

Acetic anhydride $(2 \mathrm{~mL})$ and $\mathrm{H}_{2} \mathrm{SO}_{4}(2 \mathrm{~mL})$ were added to the $\mathrm{MeOH}$ extract $(0.5 \mathrm{~g})$ and shaken. A color change from violet or light brown to deep viscous brown indicated the presence of steroids.

\section{Test for cardiac glycosides}

The $\mathrm{MeOH}$ extract $(0.5 \mathrm{~g})$ was dissolved in chloroform $(2 \mathrm{~mL})$ and filtered into a test tube. Concentrated sulfuric acid was carefully added to form a lower layer. A reddish brown-colored ring at the chloroform/sulfuric acid interphase indicated the presence of a steroidal ring or glycine of the cardiac glycosides.

\section{Antimicrobial study}

Organisms

Bacillus subtilis (National Collection of Type Culture (NCTC) 8236), Bacillus cereus (NCTC), Staphylococcus aureus (NCTC 6571), Pseudomonas aeruginosa (American Type Culture Collection (ATCC) 10145) and Escherichia coli (ATCC 25922) were used in this study.

Testing of extract and partitioned fractions for antibacterial activity

The extract and partitioned fractions $(40 \mathrm{mg} / \mathrm{mL})$ were subjected to antibacterial tests (in triplicate) against five bacterial strains [(a) Gram positive (+ve): B. subtilis, B. cereus, and S. aureus; and (b) Gram negative (-ve): P. aeruginosa and E. coli] to access the broad spectrum activity of the extract. The cup-plate agar diffusion method was adopted to assess antibacterial activity of the prepared extract and partitioned fractions. Bacterial suspension $(0.6 \mathrm{~mL})$ containing approximately $10^{5} \mathrm{cfu} / \mathrm{mL}$ was thoroughly mixed with sterile nutrient agar $(60 \mathrm{~mL})$. The inoculated nutrient agar $(20 \mathrm{~mL})$ was distributed into sterile Petri dishes and bacterial inoculum broth $(0.5$ $\mathrm{mL}$ ) was added to the respective Petri dishes. The contents of the Petri dishes were mixed thoroughly by rotary motion. The medium containing inoculum was allowed to solidify at room temperature. ${ }^{9}$ After solidification of the medium, four wells of approximately 8 $\mathrm{mm}$ diameter (at equal distance) were cut with a sterile metallic borer. Uniform volumes of different concentrations of test solution and standard solution were added to the wells in the Petri dish and labeled. The solutions were allowed to diffuse by leaving plates undisturbed for $1 \mathrm{~h}$ at room temperature. The second plate containing dimethyl sulfoxide was used as a negative control. The Petri dishes were incubated at $37 \pm 1{ }^{\circ} \mathrm{C}$ for $24 \mathrm{~h}$ and the zones of inhibition were recorded (in $\mathrm{mm}$ ) for each of the extract and fractions.
Determination of minimal inhibitory concentration (MIC)

MIC was determined using the macrobroth dilution method in test tubes. Double-strength Mueller Hinton Broth $(1 \mathrm{~mL})$ was first dispensed into the tube, then $1 \mathrm{~mL}$ of sample solution $(40 \mathrm{mg} / \mathrm{mL})$ was added. Serial dilutions were made to obtain a final concentration of $0.025 \mathrm{mg} / \mathrm{mL}$. A no-extract control sample served as the negative control, while another tube with ciprofloxacin $(2 \mathrm{mg} / \mathrm{mL})$ served as the positive control (being a broad spectrum antibacterial). The bacterial suspension $\left(5 \mu \mathrm{L}, \sim 10^{5} \mathrm{cfu} / \mathrm{mL}\right)$ was then added to each test tube. Another set of tubes containing broth was not inoculated and served as the noninoculated control. The experiment was carried out in duplicate and the tubes were incubated at $37^{\circ} \mathrm{C}$ for $24 \mathrm{~h}$. After the incubation period, samples from the tubes were subcultured on a dried duplicate Mueller Hinton Agar plate, applied using a sterile loop, before adding a drop of tetrazolium salt to each tube and inspecting for color change that indicates the presence of viable cells in the tubes. The minimum concentration inhibiting the growth of a test organism was recorded as the MIC of the test sample against the organism.

Determination of bactericidal activity and minimum bactericidal concentration $(\mathrm{MBC})$

The recovery plates, onto which the samples in each tube had been subcultured earlier, were incubated at $37^{\circ} \mathrm{C}$ for $72 \mathrm{~h}$ and observed for growth. The tubes with the minimum concentration from which no bacterial colony were observed were taken as indicative of the MBC.

\section{Column chromatography MS MeOH extracts}

A slurry of silica gel in n-hexane, free of air bubbles, was poured into a clean glass column $(4 \mathrm{~cm}$ id $\times 55 \mathrm{~cm})$ containing some $\mathrm{n}$-hexane. The crude $\mathrm{MeOH}$ extract $(10 \mathrm{~g})$ was pre-adsorbed on silica gel (30 g) and effectively transferred into the prepared column. The column was initially eluted with $100 \%$ n-hexane $(3 \times$ $100 \mathrm{~mL}$ ) and the eluent was collected in $20 \mathrm{~mL}$ portions. Gradient elution was carried out by increasing the amount of EtOAc from $0.5 \%$ to $100 \%$ and $\mathrm{DCM} / \mathrm{MeOH}$ mixtures of increasing polarity. Elution was monitored using thin-layer chromatography (TLC) analysis. The TLC plates were observed by fluorescence under UV-light, followed by staining with iodine vapor. Fractions with identical TLC patterns were combined, and 18 combined fractions were obtained.

\section{Antibacterial screening of the combined fractions}

The combined silica gel column fractions were screened for antibacterial activity; the results are presented in Supplementary Table S1. All the 18 combined fractions were tested against Bacillus species (since Bacillus species were found to be responsive to the extract). Eleven combined fractions displayed remarkable activity.

\section{Further purification of combined fractions $B, D, G, I$ and $K$}

Only five of the eleven bioactive combined fractions were available in appreciable quantity for further purification. Fraction B (0.41 g) was further fractionated by column chromatography (silica gel, mesh size 60-120). The column was eluted with solvent mixtures 
of n-hexane/EtOAc. Tubes 16-25 were combined on the basis of TLC pattern; a whitish solid precipitated, which on filtration was labeled B1/IJL ( $0.20 \mathrm{~g})$. Fraction B1 was analyzed by electrospray ionization-mass spectrometry (ESI-MS), gas chromatographymass spectrometry (GC-MS of the fatty acid methyl ester (FAME) and trimethylsilyl (TMS) derivatives), infrared spectroscopy and nuclear magnetic resonance (NMR). Combined fractions D, G, I and $\mathrm{K}$ were treated similarly and analyzed. From fraction $\mathrm{D}$ test tubes $15-22$, a solid labeled D1/IEL $(0.03 \mathrm{~g})$ was obtained. Fraction $\mathrm{G}$ yielded two solids: test tubes $7-18$, solid G1/IGL $(0.01 \mathrm{~g})$; and test tubes $25-34$, solid G2/IML $(0.08 \mathrm{~g})$. Fraction I test tubes 18-25, contained solid I/IPL ( $0.08 \mathrm{~g})$. Fraction $\mathrm{K}$ afforded two solids: test tubes 14-21, solid K1/IAL (0.02 g); and test tubes 28-35, solid K2/IIL (0.02 g).

\section{NMR spectroscopic analysis}

${ }^{1} \mathrm{H}-\mathrm{NMR}$ spectroscopic data was recorded on a $300 \mathrm{MHz}$ Agilent Technologies NMR Machine and $126 \mathrm{MHz}$ for ${ }^{13} \mathrm{C}-\mathrm{NMR}$. Chemical shifts of signals were reported in parts per million (ppm).

\section{GC analysis}

Gas chromatogram was recorded on Agilent Technologies 7890A and $5975 \mathrm{C}$ Mass Spectrometer using a HP 5 MS column $(30 \mathrm{~m} \times$ $0.32 \mathrm{~mm} \Phi, 25 \mu \mathrm{m})$. The analysis was carried out with temperature profile of $40{ }^{\circ} \mathrm{C}(1 \mathrm{~min})$ to $320^{\circ} \mathrm{C}(10 \mathrm{~min})$ at $5{ }^{\circ} \mathrm{C} / \mathrm{min}$.

\section{ESI-MS experiment}

The samples (about $1.0 \mathrm{mg}$ each of DCM and $\mathrm{CH}_{3} \mathrm{OH}$ extracts and isolates in duplicates) were added to $\mathrm{CH}_{3} \mathrm{OH}(1 \mathrm{~mL})$ and acetic acid $(10 \mu \mathrm{L})$. The mixture underwent sonication, to ensure total dissolution. Electrospray mass spectrometric analyses were performed on a Hewlett-Packard 5989A equipped with an electrospray interface 59987A. Nitrogen was used as the nebulizing gas, at a pressure of $50 \mathrm{psi}$ and a temperature of $300{ }^{\circ} \mathrm{C}$. The samples were analyzed by direct infusion $(10 \mu \mathrm{L} / \mathrm{min})$ in scan mode.

\section{GC-MS analysis of extracts and isolates as TMS derivatives}

Extracts and isolates (1.0 mg, in duplicate) were weighed and added to GC vials, to which DCM $(1 \mathrm{~mL})$ containing anthracene as an internal standard (IS) $(50 \mu \mathrm{g} / \mathrm{mL})$ was added. The samples were silylated with addition of N,O-bis(trimethylsilyl)-trifluoroacetamide (BSTFA) containing $1 \%$ trimethylchlorosilane (TMCS) $(50 \mu \mathrm{L})$ and pyridine $(50 \mu \mathrm{L})$ and heated for $30 \mathrm{~min}$ at $70{ }^{\circ} \mathrm{C}$ or longer, until the solution became clear. The prepared TMS derivatives were analyzed by GC-MS EI (FOCUS-ISQ; Thermo Scientific, Waltham, MA, USA) using the following parameters: temperature profile: $40^{\circ} \mathrm{C}(1 \mathrm{~min})$ ramped to $305^{\circ} \mathrm{C}(10 \mathrm{~min})$ at $5{ }^{\circ} \mathrm{C} /$ min; GC capillary column (RTx-5 MS, $30 \times 0.25 \mathrm{~mm} \Phi$, Restek). The eluted compounds were identified by spectral matching with the 2008 National Institute of Standard and Technology (NIST) spectral library and known standards.

\section{GC-MS analysis of FAME derivatives}

Extracts and isolates (2.0 mg, in duplicate) were weighed and add- ed to $5 \mathrm{~mL}$ vials, to which FAME reagent $(2 \mathrm{~mL}$; prepared by adding a solution of 1-naphthaleneacetic acid $(100 \mu \mathrm{g} / \mathrm{mL})$ in DCM $(50 \mathrm{~mL})$ to a mixture $(50 \mathrm{~mL})$ of $\left.\mathrm{MeOH} / \mathrm{H}_{2} \mathrm{SO}_{4}(1.7: 0.3: 2.0 \mathrm{v} / \mathrm{v} /)\right)$ was added to each vial and heated for $90 \mathrm{~min}$ at $90{ }^{\circ} \mathrm{C}$. 1-Naphthaleneacetic acid was the IS. The mixture was allowed to cool, after which water $(1 \mathrm{~mL})$ was added, and the sample was shaken vigorously and centrifuged. The $\mathrm{CHCl}_{3}$ layer was removed, dried through anhydrous sodium sulfate and transferred to $\mathrm{GC}$ vials. The prepared FAME derivatives were analyzed by $\mathrm{GC}-\mathrm{MS}$ (details given above), using the temperature profile of $40{ }^{\circ} \mathrm{C}(1 \mathrm{~min})$ to $320{ }^{\circ} \mathrm{C}$ at $5{ }^{\circ} \mathrm{C} / \mathrm{min}$. The eluted compounds were identified with authentic standards (C12 to $\mathrm{C} 20$ fatty acids) and by spectral matching with the NIST spectral library.

\section{Results and discussion}

\section{Extraction of plant material}

Soxhlet extraction of MS leaves with DCM and $\mathrm{MeOH}$ gave $2.71 \%$ and $4.48 \%$ yield respectively, a total of $7.49 \%$. These results compare favorably with the yield obtained by soaking MS leaves in cold $\mathrm{MeOH}(6 \%)$. Our previous observation ${ }^{7}$ from study of another plant material (Cola nitida) subjected to similar treatment was different: soxhlet extraction gave a total of $18.37 \%$ yield, while soaking in cold $\mathrm{MeOH}$ gave $4 \%$. Collectively, therefore, these data suggest that different plant materials may require different extraction techniques.

\section{Phytochemical screening}

The qualitative phytochemical screening of MS leaves showed the presence of alkaloids, tannins, cardiac glycoside, saponins and steroid, while no flavonoid was detected; although, an earlier report indicated the presence of flavonoid in aqueous extract of MS. ${ }^{10}$ Tannins, flavonoids, saponins, cardiac glycosides and alkaloids have been reported to exhibit antimicrobial activities. ${ }^{11,12}$

Alkaloids have antidiarrheal, antihypertensive, antifungal, anti-inflammatory and antifibrogenic effects. ${ }^{13}$ Some alkaloids are useful against human immunodeficiency virus infection as well as intestinal infection associated with acquired immunodeficiency syndrome. ${ }^{14}$ The presence of alkaloids in medicinal plants makes it recommendable for their treatment of one ailment or another, as alkaloids possess significant pharmacological properties.

Tannin is a nontoxic substance and can generate physiological responses in animals that consume it. ${ }^{15}$ However, tannin can be toxic to filamentous fungi, yeast, and bacteria. The presence of tannin in medicinal plants suggests the ability of the plant to play major roles as an antifungal, antidiarrheal, antioxidant and antihemorrhoidal agent. ${ }^{16}$ The antibacterial properties of tannins have been documented. ${ }^{17}$

Saponins have been reported to have antihyper-cholesterol, anti-inflammatory, cardiac depressant properties and appear to kill or inhibit cancer cells without killing normal cells in the process. ${ }^{18,19}$

Steroids are biologically active organic compounds with four rings. They constitute important components of cell membranes which alter membrane fluidity and act as signaling molecules. ${ }^{20}$ Steroids play critical roles in a number of disorders, including malignancies like prostate cancer and as anti-inflammatory agents. ${ }^{21}$

Cardiac glycoside has been used for over two centuries as a 
Table 1. The zone of inhibition $(\mathrm{mm})$ of crude methanol extract of $\mathrm{MS}$ and fractions against selected bacteria

\begin{tabular}{|c|c|c|c|c|c|c|c|}
\hline Organism & $\mathrm{MeOH}$ extract & EtOAc fraction & Hexane fraction & Butanol fraction & $\begin{array}{l}\text { Ciprofloxacin } \\
2 \mathrm{mg} / \mathrm{mL}\end{array}$ & DMSO & Blank \\
\hline E.coli (ATCC 25922) & 0 & 0 & 0 & 0 & 17 & 0 & 0 \\
\hline P. aeruginosa (ATCC 10145) & 0 & 0 & 0 & 0 & 19 & 0 & 0 \\
\hline B. subtilis (NCTC 8236) & 13 & 15 & 13 & 0 & 19 & 0 & 0 \\
\hline S. aureus (NCTC 6571) & 0 & 0 & 0 & 0 & 15 & 0 & 0 \\
\hline B. cereus (NCTC) & 12 & 15 & 11 & 0 & 17 & 0 & 0 \\
\hline
\end{tabular}

DMSO, dimethyl sulfoxide; MS, Melanthera scandens.

stimulant in cases of cardiac failure and diseases. ${ }^{22,23}$ This, perhaps, justifies the local use of MS in the treatment and management of hypertension. ${ }^{24}$

\section{Antibacterial activity}

In-vitro activity of the extract and fractions against selected bacteria

The zone of inhibition (the diameter of the circular region around the well, where there was no microbial growth) due to EtOAc fraction was $15 \mathrm{~mm}$ for both $B$. subtilis and $B$. cereus; there was no inhibition of growth for E. coli, P. aeruginosa, and S. aureus. The crude $\mathrm{MeOH}$ extract exhibited a zone of inhibition of $13 \mathrm{~mm}$ and $12 \mathrm{~mm}$ against $B$. subtilis and $B$. cereus respectively and no inhibition of growth on E. coli, P. aeruginosa, and S. aureus. The n-hexane fraction displayed zones of inhibition of $12 \mathrm{~mm}$ and 11 $\mathrm{mm}$ for B. subtilis and B. cereus but also no inhibition of growth on E. coli, P. aeruginosa, and $S$. aureus. The n-butanol fraction showed no inhibition of growth for any of the bacterial strains tested. The result is shown in Table 1. This result showed that bioactivity of the MS leaf is centered in the EtOAc fraction; hence, it was considered for further chemical examination. To note, among the tested microbes, only Bacillus species were responsive to the activity of MS crude $\mathrm{MeOH}$ extract and fractions. The activity of the EtOAc fraction against Basillus species was comparable to that of ciprofloxacin.

MIC and MBC of the EtOAc fraction

The MIC of the EtOAc fraction against the Bacillus species was investigated, as well as its MBC. MIC of $0.313 \mathrm{mg} / \mathrm{mL}$ was observed on $B$. subtilis and $B$. cereus, while the MBC value of $>40$ $\mathrm{mg} / \mathrm{mL}$ was obtained for the EtOAc fraction. However, the high MIC value implies higher dose for effective treatment compared to ciprofloxacin. When $\mathrm{MS} \mathrm{MeOH}$ extract was administered to experimental animals (mice), the $\mathrm{LD}_{50}$ of 1625 was observed, ${ }^{5}$ implying a high safe dose for treating animals with MS extract against microbial attack.

\section{Chemical constituents analysis}

GC-MS analysis of n-hexane fraction

The n-hexane fraction was analyzed by GC-MS and compounds identified based on NIST 08 MS library matching (Table 2). The

Table 2. Compounds detected in the GC-MS analysis of $n$-hexane extract

\begin{tabular}{llll}
\hline Compound name & Formula & Retention time in min & Area, \% \\
\hline Caryophyllene oxide & $\mathrm{C}_{15} \mathrm{H}_{24} \mathrm{O}$ & 13.15 & 0.66 \\
2,6,6-Trimethyl-bicyclo[3.1.1]heptane & $\mathrm{C}_{10} \mathrm{H}_{18}$ & 15.48 & 1.82 \\
6,10,14-Trimethyl-2-pentadecanone & $\mathrm{C}_{15} \mathrm{H}_{36} \mathrm{O}$ & 15.57 & 0.67 \\
1-Hexadecyne & $\mathrm{C}_{16} \mathrm{H}_{30}$ & 15.71 & 0.50 \\
Methyl hexadecanoate & $\mathrm{C}_{17} \mathrm{H}_{34} \mathrm{O}_{2}$ & 16.11 & 2.15 \\
n-Hexadecanoic acid & $\mathrm{C}_{16} \mathrm{H}_{32} \mathrm{O}_{2}$ & 16.81 & 1.04 \\
15-Methyl-methylhexadecanoate & $\mathrm{C}_{18} \mathrm{H}_{36} \mathrm{O}_{2}$ & 17.14 & 0.67 \\
Methyl-9,12-octadecadienoate & $\mathrm{C}_{19} \mathrm{H}_{34} \mathrm{O}_{2}$ & 17.75 & 11.07 \\
Methyl-9,12,15-octadecatrienoate & $\mathrm{C}_{19} \mathrm{H}_{32} \mathrm{O}_{2}$ & 17.84 & 20.94 \\
Phytol & $\mathrm{C}_{20} \mathrm{H}_{40} \mathrm{O}$ & 17.95 & 26.03 \\
17-Chloro-7-heptadecyne & $\mathrm{C}_{17} \mathrm{H}_{31} \mathrm{Cl}$ & 18.18 & 2.25 \\
Methyl-9-cis,11-trans,13-trans-octadecatrienoate & $\mathrm{C}_{19} \mathrm{H}_{32} \mathrm{O}_{2}$ & 18.87 & 0.73 \\
Methyl-18-methylnonadecanoate & $\mathrm{C}_{19} \mathrm{H}_{42} \mathrm{O}_{2}$ & 19.58 & 0.42 \\
2,3-Epoxyandrostan-17-ol & $\mathrm{C}_{19} \mathrm{H}_{30} \mathrm{O}_{2}$ & 19.69 & 3.92 \\
\hline
\end{tabular}


Table 3. GC-MS analysis of DCM extract of MS (FAME derivatives)

\begin{tabular}{lllll}
\hline Retention time in min & Compound & Molecular formula & MW & \% Extract \\
\hline 27.36 & Methyl naphthaleneacetate (IS) & $\mathrm{C}_{13} \mathrm{H}_{12} \mathrm{O}_{2}$ & 200 & 1.23 \\
30.92 & Photocitral A & $\mathrm{C}_{10} \mathrm{H}_{16} \mathrm{O}$ & 152 & 12.06 \\
53.19 & Olean-12-ene-3-one & $\mathrm{C}_{30} \mathrm{H}_{48} \mathrm{O}$ & 424 & 6.06 \\
53.27 & Hop 22 (29)-en-3-one & $\mathrm{C}_{30} \mathrm{H}_{48} \mathrm{O}$ & 424 & 3.44 \\
53.47 & Olean-12-en-3-yl acetate & $\mathrm{C}_{32} \mathrm{H}_{52} \mathrm{O}_{2}$ & 468 & 1.40 \\
53.56 & Olean-12-en-3-ol & $\mathrm{C}_{30} \mathrm{H}_{50} \mathrm{O}$ & 426 & 426 \\
53.73 & Lup-20(29)-en-3-ol (Lupeol) & $\mathrm{C}_{30} \mathrm{H}_{50} \mathrm{O}$ & 4.53 \\
\hline
\end{tabular}

FAME, fatty acid methyl ester; IS: internal standard; MS, Melanthera scandens; MW, molecular weight.

14 components identified included phytol (26\%), methyl-9,12,15octadecatrienoate $(20.9 \%)$, and methyl-9,12-octadecadienoate $(11.1 \%)$ as the main components. Phytol is an acyclic diterpene alcohol.

\section{Analysis of MS leaf DCM and $\mathrm{CH}_{3} \mathrm{OH}$ extracts}

\section{ESI-MS analysis}

Five compounds were tentatively identified in the positive ion ESI-MS analysis of the DCM extract; the mass spectrum is shown in Supplementary Figure S1. 3-O- $\beta$-D-glucuronopyranosyl-28O- $\beta$-D-glucopyranosyl-oleanolate (GrGOa) gave low intensity ions at $\mathrm{m} / \mathrm{z} 795,799,903$ corresponding to $[\mathrm{M}+\mathrm{H}]^{+}(12 \%)$, $[\mathrm{M}$ $+5 \mathrm{H}]^{+}(20 \%),\left[\mathrm{M}+\mathrm{H}+6 \mathrm{H}_{2} \mathrm{O}\right]^{+}(25 \%)$ and a high intensity ion at $\mathrm{m} / \mathrm{z} 1029$ corresponding to $\left[\mathrm{M}+\mathrm{H}+13 \mathrm{H}_{2} \mathrm{O}\right]^{+}(70 \%)$. 3 $3-\mathrm{O}-$ $[\alpha$ rhamnopyranosyl- $(1 \rightarrow 6)-\beta$-glucopyranosyl- $(1 \rightarrow 3)$-ursan-12ene (RGUe) gave rise to high intensity ions with $\mathrm{m} / \mathrm{z} 1015,871$ corresponding to $\left[\mathrm{M}+\mathrm{H}+17 \mathrm{H}_{2} \mathrm{O}\right]^{+}(70 \%)$, $\left[\mathrm{M}+\mathrm{H}+9 \mathrm{H}_{2} \mathrm{O}\right]^{+}$ $(100 \%)$ and a less intensity ion at $\mathrm{m} / \mathrm{z} 925$ corresponding to $[\mathrm{M}$ $\left.+\mathrm{H}+12 \mathrm{H}_{2} \mathrm{O}\right]^{+}(48 \%)$. 3-O- $\{[\beta-\mathrm{D}$-glucopyranosyl $(1 \rightarrow 2)][\beta-\mathrm{D}-$ xylopyranosyl $(1 \rightarrow 4)] \quad \beta$-D-glucuronopyranosyl $\}$-oleanolic acid (GXGrOA) gave low intensity ion at $\mathrm{m} / \mathrm{z} 969$ corresponding to $\left[\mathrm{M}+\right.$ acetyl $^{+}(22 \%)$. 3-O- $\{[\beta$-D-glucopyranosyl $(1 \rightarrow 2)][\beta-\mathrm{D}$ xylopyranosyl $(1 \rightarrow 4)] \beta$-D-glucuronopyranosyl $\}-28-O-\beta$-D- glucopyranosyl-oleanolate (GXGrGOa) gave rise to low intensity ions with $\mathrm{m} / \mathrm{z} 1111$ and 1127 corresponding to $[\mathrm{M}+\mathrm{Na}]^{+}(18 \%)$ and $[\mathrm{M}+\mathrm{K}]^{+}(25 \%)$ respectively. $3 \beta$-acetoxyolean-12-ene (AoOe) gave rise to moderately intense ion at $\mathrm{m} / \mathrm{z} 955$ corresponding to $[\mathrm{M}$ $\left.+\mathrm{H}+27 \mathrm{H}_{2} \mathrm{O}\right]^{+}(58 \%)$.

The following five compounds were also identified in the methanol extract (Supplementary Fig. S2): GrGOa at m/z 903 and 1029 corresponding to $\left[\mathrm{M}+\mathrm{H}+6 \mathrm{H}_{2} \mathrm{O}\right]^{+}(16 \%)$ and $\left[\mathrm{M}+\mathrm{H}+13 \mathrm{H}_{2} \mathrm{O}\right]^{+}$ (24\%) respectively; RGUe at $\mathrm{m} / \mathrm{z} 925$ corresponding to $[\mathrm{M}+\mathrm{H}$ $\left.+12 \mathrm{H}_{2} \mathrm{O}\right]^{+}(100 \%)$; AoOe at $\mathrm{m} / \mathrm{z} 955$ corresponding to $[\mathrm{M}+\mathrm{H}+$ $\left.27 \mathrm{H}_{2} \mathrm{O}\right]^{+}(55 \%)$; and GXGrOA at $\mathrm{m} / \mathrm{z} 927$ corresponding to $[\mathrm{M}+$ $\mathrm{H}^{+}(25 \%)$ and GXGrGOa at with $\mathrm{m} / \mathrm{z} 1111$ corresponding to [M $+\mathrm{Na}]^{+}(20 \%)$.

GC-MS analysis of DCM extract (FAME derivatives)

Five of the six compounds identified and quantified in the DCM extract (Supplementary Fig. S3, Table 3), after methanolysis, belong to oleanane and lupane triterpenoid series. The major component was olean-12-en-3-one, the oxidized product of olean-12-en-3-ol. The presence of olean-12-en-3yl acetate (3- $\beta$-acetoxyolean-12ene) in the extract was supported by the ESI-MS result (Supplementary Fig. S1) and in agreement with the report of Penders and Delaude. ${ }^{6}$

GC-MS analysis of DCM extract (TMS derivative)

The DCM extract was also quantitatively analyzed by GC-MS for its TMS derivatives (Table 4). The analysis revealed the presence of eight different compounds, the major constituents being methyl3-oxo-urs-12-en-24-oate and hop-22(29)-en-3-one.

Table 4. GC-MS analysis of DCM extract of MS (TMS derivatives)

\begin{tabular}{lllll}
\hline Retention time in $\min$ & Compound & Molecular formula & MW & \% Extract \\
\hline 7.45 & Acetamide TMS & $\mathrm{C}_{5} \mathrm{H}_{13} \mathrm{NOSi}$ & 131 & 0.39 \\
8.39 & Ethylamine bis-TMS & $\mathrm{C}_{8} \mathrm{H}_{23} \mathrm{NSi}_{2}$ & 189 & 0.52 \\
30.21 & Anthracene (IS) & $\mathrm{C}_{14} \mathrm{H}_{10}$ & 178 & 264 \\
31.06 & $7,11,15-$ Trimethyl-3-methylenehexadec-1-ene & $\mathrm{C}_{19} \mathrm{H}_{36}$ & 328 & 0.01 \\
35.12 & Hexadecanoate TMS & $\mathrm{C}_{19} \mathrm{H}_{40} \mathrm{O}_{2} \mathrm{Si}$ & 43 \\
53.51 & Stigmasterol TMS ether & $\mathrm{C}_{32} \mathrm{H}_{56} \mathrm{OSi}$ & 0.41 \\
53.94 & Methyl-3-oxo-urs-12-en-24-oate & $\mathrm{C}_{31} \mathrm{H}_{48} \mathrm{O}_{3}$ & 468 & 2.06 \\
54.04 & Hop-22(29)-en-3-one & $\mathrm{C}_{30} \mathrm{H}_{48} \mathrm{O}$ & 424 & 1.21 \\
55.41 & Olean-12-en-3-ol & $\mathrm{C}_{30} \mathrm{H}_{50} \mathrm{O}$ & 426 & 0.96 \\
\hline
\end{tabular}

IS, internal standard; MS, Melanthera scandens; MW, molecular weight; TMS: trimethylsilyl. 
Table 5. GC-MS analysis of G1 (TMS derivatives)

\begin{tabular}{lllll}
\hline Retention time in min & Compound & Molecular formula & MW & \% Extract \\
\hline 27.78 & 9-Decenoate-TMS & $\mathrm{C}_{13} \mathrm{H}_{26} \mathrm{O}_{2} \mathrm{Si}$ & 242 & 0.30 \\
28.23 & Carveol-TMS & $\mathrm{C}_{13} \mathrm{H}_{24} \mathrm{OSi}$ & 224 & 0.02 \\
35.23 & Hexadecanoic acid-TMS & $\mathrm{C}_{19} \mathrm{H}_{40} \mathrm{O}_{2} \mathrm{Si}$ & 328 & 0.02 \\
41.69 & 19-Norandrosterone-TMS & $\mathrm{C}_{24} \mathrm{H}_{44} \mathrm{O}_{2} \mathrm{Si}_{2}$ & 420 & 0.07 \\
41.77 & 1-Heneicosanol-TMS & $\mathrm{C}_{24} \mathrm{H}_{52} \mathrm{OSi}$ & 384 & 0.12 \\
\hline
\end{tabular}

MW, molecular weight; TMS: Trimethylsilyl.

\section{Chemical constituents of bioactive isolates}

Analysis of fraction B1

$\mathrm{n}$-Hexadecanoic acid was the main compound identified in the negative ion ESI-MS of B1, [M-H] $]^{-}$m/z 255 (100\%). Minor components included methylhexadecanoate, methyl-9-octadecenoate, methyl octadecanoate and methyl eicosanoate m/z 269 (27\%), 295 (11\%), $297(26 \%)$ and $325(33 \%)$ respectively (Supplementary Fig. S4).

Fraction B1 was also analyzed by GC-MS for its TMS derivatives. TMS hexadecanoate was the main constituent $(7.2 \%$ of extract), followed by TMS octadecanoate $(0.55 \%$ of extract). Thus, n-hexadecanoic acid was the main constituent of B1; this was ascertained by the ESI-MS, FAME and TMS GC-MS analyses results.

\section{NMR spectroscopy of B1}

${ }^{1} \mathrm{H}-\mathrm{NMR}\left(400 \mathrm{MHz}, \mathrm{CDCl}_{3}, \delta \mathrm{ppm}\right)$ showed the presence of methylene protons at upfield region $\delta$ values $2.35,1.64,1.28$ and methyl protons at $\delta 0.90 \mathrm{ppm}$. No olefinic or aromatic proton was observed. Additional findings were ${ }^{13} \mathrm{C}-\mathrm{NMR}\left(100 \mathrm{MHz}, \mathrm{CDCl}_{3}\right.$, $\delta \mathrm{ppm}) 180.39(\mathrm{C}=\mathrm{O}$ carbon typical of carboxylic acids) $34.29-$ 22.87 (methylene carbon atoms), and 14.26 methyl carbon. The NMR data above are in agreement with literature values for hexadecanoic acid. ${ }^{7}$

\section{Analysis of fraction D1}

Isolated fraction D1 was analyzed by positive ion ESI-MS, and the major peak at $\mathrm{m} / \mathrm{z} 917(100 \%)$ was unidentified (Supplementary Fig. S5). Tentatively identified components in D1 included eupalestin as $\left[\mathrm{M}+\mathrm{H}+\mathrm{nH}_{2} \mathrm{O}\right]^{+}, \mathrm{n}=9$ at m/z 579; 3- $\beta$-Dglucuronopyranosyl-oleanolic acid as $[\mathrm{M}+\mathrm{nH}]^{+}, \mathrm{n}=7$ at $\mathrm{m} / \mathrm{z}$ 639 , and 3- $\beta$-D-glucuronopyranosyl (4-1) $\beta$-D-xylopyranosyloleanolic acid as $[\mathrm{M}+\mathrm{K}]^{+}$at $\mathrm{m} / \mathrm{z} 803$.

Fraction D1 was methanolyzed and analyzed by GC-MS, showing the presence of methyl hexadecanoate.

Fraction D1 was also analyzed by GC-MS for its TMS derivative and showed mainly the presence of hexadecanoate-TMS (1.66\% of extract) together with minor amounts of octadecanoateTMS $(0.11 \%$ of extract $)$

Analysis of fraction G1

Fraction G1 was analyzed by GC-MS as its TMS derivatives, show- ing the presence of 9-decenoate-TMS together with minor amounts of 1-heneicosanol-TMS plus three other compounds (Table 5).

Analysis of fraction G2

Fraction G2 was methanolyzed and analyzed by GC-MS, showing the presence of 1,3-dimethyl-2-(1-methylethylidene)-cyclopentane $(0.83 \%$ of extract), 2,2-dimethyl-3,4-octadienal ( $1.84 \%$ of extract), and methyl hexadecanoate (1.31\% of extract).

Fraction G2 was also analyzed by GC-MS for its TMS derivatives, showing the presence of 3,7,11,15-tetramethyl-2-hexadecen1 -ol $(0.76 \%$ of extract), hexadecanoate-TMS $(0.06 \%$ of extract $)$, and anthranilic acid- $\mathrm{TMS}_{2}(0.04 \%$ of extract $)$.

\section{Analysis of fraction I}

Fraction I was methanolyzed and analyzed by GC-MS and showed the presence of 9,10-dimethyltricyclo[4.2.1.1(2,5)]decane-9,10diol $(2.58 \%$ of extract) together with methyl hexadecanoate (1.02\% of extract).

Fraction I was also analyzed by GC-MS for its TMS derivatives, showing the presence of indole-5-carboxylic acid-TMS $2(1.17 \%$ of extract), 4-hydroxybenzoic acid-TMS 2 ( $0.08 \%$ of extract), and paminosalicylic acid-TMS $(0.08 \%$ of extract).

\section{Analysis of fraction K1}

Positive ion ESI-MS analysis of fraction K1 showed the presence of three compounds (Supplementary Fig. S6). 3-O-[ $[\beta-D-$ xylopyranosyl $(1 \rightarrow 4) \quad \beta$-D-glucuronopyranosyl]-oleanolic acid was identified as moderately intense ion at $\mathrm{m} / \mathrm{z} 803$ corresponding to $[\mathrm{M}+\mathrm{K}]^{+}(52 \%)$. Methyl hexadecanoate gave low intensity ion at $\mathrm{m} / \mathrm{z} 288$ (36\% of extract), which resulted from the gain of water molecule $\left[\mathrm{M}+\mathrm{H}_{2} \mathrm{O}\right]^{+}$. Dihydro-lycopsamine ion showed at $\mathrm{m} / \mathrm{z}$ $302\left(29 \%\right.$ of extract), as a result of protonation $[\mathrm{M}+\mathrm{H}]^{+}$.

Fraction K1 was also methanolyzed and analyzed by GC-MS and showed the presence of typical FAME derivatives, mainly methyl-hexadecanoate. The results are given in Table 6 .

Fraction K1 was analyzed by GC-MS for its TMS derivatives (Table 7). The analysis revealed the presence of 12 different compounds, with squalene, trimethylsilyl tetradecanoate, n-hexadecanoic acid, octadecenoic acid, pentadecanoic acid and cholest-5-en3-ol-propanoate as the major constituents.

Analysis of fraction K2

Positive ion ESI-MS tentatively identified four compounds 
Table 6. GC-MS analysis of isolated solid K1 (FAME derivative)

\begin{tabular}{lllll}
\hline Retention time in min & Compound & Molecular formula & MW & \% Extract \\
\hline 25.01 & 1,1-Dimethoxy-octane & $\mathrm{C}_{10} \mathrm{H}_{22} \mathrm{O}_{2}$ & 174 & 3.17 \\
27.36 & Methyl naphthaleneacetate (IS) & $\mathrm{C}_{13} \mathrm{H}_{12} \mathrm{O}_{2}$ & 200 & \\
31.91 & Methyl hexadecanoate & $\mathrm{C}_{17} \mathrm{H}_{34} \mathrm{O}_{2}$ & 270 & 30.2 \\
35.20 & Methyl oleate & $\mathrm{C}_{19} \mathrm{H}_{36} \mathrm{O}_{2}$ & 296 & 1.81 \\
35.68 & Methyl octadecanoate & $\mathrm{C}_{19} \mathrm{H}_{38} \mathrm{O}_{2}$ & 298 & 1.40 \\
\hline
\end{tabular}

FAME, fatty acid methyl ester; IS, internal standard; MW, molecular weight.

(Supplementary Fig. S7) which are: those being lycopsamine N-oxide; oleanolic acid; 3-O-[ $\beta$-D-xylopyranosyl $(1 \rightarrow 4) \beta$-Dglucuronopyranosyl]-oleanolate and 3-O-[ $\beta$-D-xylopyranosyl $(1 \rightarrow 4) \beta$-D-glucuronopyranosyl]-28-O- $\beta$-D-glucopyranosyloleanolate, which were observed at $\mathrm{m} / \mathrm{z} 316,479,806$ and 949 corresponding to $[\mathrm{M}+\mathrm{H}]^{+}\left(62 \%\right.$ of extract), $[\mathrm{M}+\mathrm{Na}]^{+}(34 \%$ of extract), $[\mathrm{M}+\mathrm{OAc}]^{+}(45 \%$ of extract $)$ and $[\mathrm{M}+\mathrm{Na}]^{+}(35 \%)$ respectively.

The presence of dihydro-lycopsamine, lycopsamine N-oxide and eupalestin have been reported in the Ageratum conyzoides family Asteraceae.$^{25} 3 \beta$-acetoxyolean-12-ene and $3 \beta$-O-[ $\alpha$-rhamnopyranosyl$(1 \rightarrow 6)$ - $\beta$-glucopyransyl-( $1 \rightarrow 3$ )-ursan-12-ene identified in the DCM and methanol extracts of MS have been reported in the Aspilia africa$n a$ family Asteraceae ${ }^{26}$ Oleanolic acid, GrOA, GXGrOA, GXGrOA, GrGOa, GXGrGOa and XGrGOa have been previously reported in MS. $^{6}$

\section{Conclusions}

This study concluded that the crude $\mathrm{MeOH}$ extract, which was found to contain alkaloids, tannins, cardiac glycoside, saponins and steroids, inhibited the activities of Bacillus species considerably, among the microbes tested. The EtOAc solvent partitioned fraction was the most active, while the butanol fraction showed no activity. Many of the compounds identified in the MS extract in this work have been previously reported to have biological activity. Phytol, a diterpene alcohol and the major constituent of the n-hexane extract, is known to inhibit inflammatory response by reducing cytokine production and oxidative stress. ${ }^{27} 1$-Heneicosanol exhibited antimicrobial activity. ${ }^{28}$ Oleanolic acid, a pentacyclic triterpenoid, and its derivatives exhibited several pharmacological activities, such as hepatoprotective, anti-inflammatory, antioxidant and antitumor, among others. ${ }^{29,30}$ Longchain fatty acids, such as hexadecanoic acid, octadecanoic acid, pentadecanoic acid, etc., have been reported several times over to possess various biological activities, including antimicrobial. ${ }^{31,32}$ These chemical compounds are responsible for the bioactivities of the MS extract, including those of antibacterial, wound healing, anti-skin infections, antigastroenteritis, anti-inflammatory, antidiuretic, and antihypertensive, among others. These justify its use in ethno-medicine to manage diseases caused by pathogenic microorganisms.

Future research direction

The plant MS is used in both man and animals. We have reported our previous study of its toxicity in our earlier report, and the plant could be classified as nontoxic based on our findings. However,

Table 7. GC-MS analysis of isolated solid K1 (TMS derivative)

\begin{tabular}{|c|c|c|c|c|}
\hline Retention time in min & Compound & Molecular formula & MW & \% Extract \\
\hline 27.22 & Dodecanoic acid, TMS & $\mathrm{C}_{15} \mathrm{H}_{32} \mathrm{O}_{2} \mathrm{Si}$ & 272 & 1.58 \\
\hline 29.54 & Tetradecanoic acid (myristic) & $\mathrm{C}_{14} \mathrm{H}_{28} \mathrm{O}_{2}$ & 228 & 1.22 \\
\hline 30.15 & Anthracene (IS) & $\mathrm{C}_{14} \mathrm{H}_{10}$ & 178 & \\
\hline 31.39 & Tetradecanoic acid TMS & $\mathrm{C}_{17} \mathrm{H}_{36} \mathrm{O}_{2} \mathrm{Si}$ & 284 & 13.47 \\
\hline 31.60 & Pentadecanoic acid & $\mathrm{C}_{15} \mathrm{H}_{30} \mathrm{O}_{2}$ & 242 & 5.90 \\
\hline 33.19 & Z-11-Hexadecenoic acid & $\mathrm{C}_{16} \mathrm{H}_{30} \mathrm{O}_{2}$ & 254 & 3.23 \\
\hline 33.33 & TMS pentadecanoate & $\mathrm{C}_{18} \mathrm{H}_{38} \mathrm{O}_{2} \mathrm{Si}$ & 314 & 1.46 \\
\hline 33.65 & n-Hexadecanoic acid & $\mathrm{C}_{16} \mathrm{H}_{32} \mathrm{O}_{2}$ & 256 & 12.25 \\
\hline 36.88 & 9-Octadecenoic acid & $\mathrm{C}_{18} \mathrm{H}_{34} \mathrm{O}_{2}$ & 282 & 6.72 \\
\hline 37.27 & Stearic acid & $\mathrm{C}_{18} \mathrm{H}_{36} \mathrm{O}_{2}$ & 284 & 1.61 \\
\hline 40.06 & Squalene & $\mathrm{C}_{30} \mathrm{H}_{50}$ & 410 & 26.20 \\
\hline 46.78 & Cholesta-3,5-diene & $\mathrm{C}_{27} \mathrm{H}_{44}$ & 368 & 2.39 \\
\hline 48.29 & 4,6-Cholestadien-3-ol & $\mathrm{C}_{27} \mathrm{H}_{44} \mathrm{O}$ & 384 & 1.52 \\
\hline 48.58 & Cholest-5-en-3-ol propanoate & $\mathrm{C}_{30} \mathrm{H}_{50} \mathrm{O}_{2}$ & 442 & 4.80 \\
\hline
\end{tabular}

IS, internal standard; MW, molecular weight; TMS, trimethylsilyl. 
there is still need for biochemical studies to determine its effect on internal organs in experimental animals.

Many of the chemical constituents of MS have been identified in the course of these detailed analyses. Since the ESI-MS analysis showed that there are some unidentified chemical components yet, future research should focus on identifying these.

A lot of screenings on antimicrobial activity of MS have been carried out by various authors, including those shown in our previous report, but there is need to screen the extract of this plant further against cancer cells and for its anti-inflammatory potentials among other biological activities.

\section{Acknowledgments}

We wish to acknowledge the University of Idaho, Moscow, USA, for the offer of a 6-month Research Scientist position, which afforded Armando G. McDonald the opportunity to carry out the analyses reported in this work.

\section{Conflict of interest}

The authors declare there is no conflict of interest related to this publication.

\section{Author contributions}

The owner of research idea and supervisor of the project (JKA), carrying out the experiments (ISA), assisting in supervision of the project when JKA travelled to USA for a six months research project in Armando's laboratory (OSA), assisting with spectroscopic analysis (GMA).

\section{Supporting information}

Supplementary material for this article is available at https://doi. org/10.14218/JERP.2019.00007.

Table S1. Antibacterial screening of the combined fractions.

Table S2. GC-MS analysis of methanolyzed fraction B1.

Fig. S1. Positive ion ESI-MS of DCM extract of Melanthera scandens leaf. DCM, dichloromethane.

Fig. S2. Positive ion ESI-MS of methanol extract of Melanthera scandens leaf.

Fig. S3. Total ion current chromatogram of DCM extract (FAME derivatives). DCM, dichloromethane; FAME, fatty acid methyl ester.

Fig. S4. ESI-MS of isolated solid B1 (negative mode). The B1 fraction was methanolyzed and analyzed by GC-MS (FAME derivatives) and results given in Supplementary Table S2. The major compound detected was hexadecanoic acid methyl ester (63\%). Other minor constituents were methyloctadecanoate and methyl9-octadecenoate. FAME, fatty acid methyl ester.

Fig. S5. Positive ion ESI-MS of fraction D1.
Fig. S6. Positive ion ESI-MS of fraction K1.

Fig. S7. Positive ion ESI-MS of fraction K2.

\section{References}

[1] Brenan PM. Flora of Tropical East Africa. East Africa Literature Bureau, Nairobi. 1996:3-7.

[2] Burkill HM. The useful plants of West Tropical Africa, 2nd Edition. London: Royal Botanic Garden. 1985:127.

[3] Omotayo FO. Vascular plants in Nigeria. Afr J Sci 2007;4:14-144.

[4] Watt JM, Breyer-Brandwijk MG. The medicinal and poisonous plants of Southern and Eastern Africa. E \& S Livingstone. 1962:47.

[5] Adesanwo JK, Egbomeade CO, Moronkola DO, Akinpelu DA. Chemi$\mathrm{cal}$, toxicity and antibacterial studies on methanol extracts of $\mathrm{Mel}$ anthera scandens, Ageratum conyzoides, Aspilia Africana and Syndrella nodiflora. J Explor Res Pharmacol 2019;4:1-7. doi:10.14218/ JERP.2018.00013.

[6] Penders A, Delaude C. Triterpenoids saponins from melanthera scadens. Phytochemistry 1994;37(3):821-825. doi:10.1016/S00319422(00)90364-9.

[7] Adesanwo JK, Ogundele SB, Akinpelu DA McDonald AG. Chemical analyses, antimicrobial and antioxidant activities of extracts from Cola nitida Seed. J Explor Res Pharmacol 2017;2:67-77. doi:10.14218/JERP.2017.00015.

[8] Trease G, Evans W. Pharmacognosy, 15th edition. Sanders publishing company. 2002:221-224, 230.

[9] Prescott LM, Harley JP, Klein DA. Microbiology, 2nd edition. OxfordBrown Publishers. 1990:328.

[10] Daniel IE, US Ekam. Preliminary phytochemical screening and toxic effect of melanthera scandens leaf extracts using brine shrimp (Artemia salina) Test. Journal of Complementary and Alternative Medical Research 2016;1(3):1-7. doi:10.14218/JERP.2017.00015.

[11] Isaac OO, Chinwe JA. The phytochemical analysis and antibacterial Screening of extracts of Tetracarpidium conophorum. J Chem Soc Niger 2001;26:53-55.

[12] Hostettmann K, Marston A, Wolfender JL. Strategy in the search for new biologically active plant constituents. In: Hostettmann K, Marston A, Maillard M, Hamburger M. (eds.), Phytochemistry of Plants Used in Traditional Medicine. Oxford: Clarendon Press. 1995:17-45.

[13] Ghoshal S, Prasad BN, Lakshmi V. Anti amoebic activity of Piper longum fruits against Entamoeba histolytica in-vivo. J Ethnopharmacol 1996;50:167-170. doi:10.1016/0378-8741(96)01382-7.

[14] McDevitt JT, Schneider DM, Katiyar SK, Edlind FS. Berberina: a candidate for the treatment of diarrhea in AIDS patients abstracts. 175. In program and Abstracts of the 36th Interscience conference on Antimicrobial Agents and Chemotherapy. American Society for Microbiology, Washington, D.C. 1996.

[15] Scalbert A. Antimicrobial properties of tannis. Phytochemistry 1991;30:3875-3882. doi:10.1016/0031-9422(91)83426-L.

[16] Asquith TN, Butter LG. Interaction of condensed tannins with selected proteins. Phytochemistry 1986;25(7):1591-1593. doi:10.1016/ S0031-9422(00)81214-5.

[17] Banso A, Adeyemo SO. Evaluation of antibacterial properties of tannins isolated from dichrostachys cinereal. Afr J Biotechnol 2007;6(15):1785-1787. doi:10.5897/AJB2007.000-2262.

[18] Trease GE, Evans WC. Pharmacognosy, 11th Edition. London: Tindal Limited. 1985:60-75.

[19] Lewis WH, Elvin-Lewis MP. Medicinal plants as sources of new therapeutics. Ann Mo Botany Garden 1995;82:16-24. doi:10.2307/2399976.

[20] Sadava D, Hillis DM, Heller HL, Berenbaum MR. Life: The science of biology, 9th Edition. San Francisco: Freeman. 2011:105-114.

[21] Lubik AA, Gunter JH, Hollier BG, Ettinger S, Fazli L, Stylianou N, et al. IGF2 increases de novo steroidogenesis in prostate cancer cells. Endocr Relat Cancer 2013;22 20(2):173-186. doi:10.1530/ERC-12-0250.

[22] Olayinka AO, Onoruvwe O, Lot TY. Cardiovascular effects of Methanolic extract of the stem bark of Khaya senegalensis. Phytother Res 
1992;6(5):282-284. doi:10.1002/ptr.2650060513.

[23] Trease GE, Evans WC. Pharmacology, 11th Edition. London: Bailliere Tindal Limited. 1978:60-75.

[24] Abidemi TA, Adebayo OJ, Idowu O, Agbotoba MO. Nutrient content and antinutritionl factor in Shea butter (Butryospermum parkii) leaves. Afr J Biotechnol 2009;8(21):5888-5890. doi:10.5897/ AJB09.593.

[25] Bosi CF, Rosa DW, Grougnet R, Lemonakis N, Halabalaki M, Skaltsounis AL, Biavatti MW. Pyrrolizidine alkaloids in medicinal tea of Ageratum conyzoides. Brazilian Journal of Pharmacognosy 2013;23(3):425432. doi:10.1590/S0102-695X2013005000028.

[26] Faleye FJ. Terpenoid constituents of Aspilia Africana. J Ethnopharmacol 2012;13(1):138-142.

[27] Silva RO, Sousa F, Damasceno SRB, Carvalho NS. Phytol, a diterpene alcohol, inhibits the inflammatory response by reducing cytokine production and oxidative stress. Fundam Clin Pharmacol 2014;28(4):455-464. doi:10.1111/fcp.12049.
[28] Arancibia LA, Naspi CV, Pucci GN, Arce ME, Colloca CB. Biological activity of 1-heneicosanolisolated from Senecio coluhuapiensis, an endemic species from Patagonia, Argentina. The Pharmaceutical and Chemical Journal 2016;3(4):73-77.

[29] Sifaoui I, López-Arencibia A, Martín-Navarro CM, Reyes-Batlle M, Mejri M, Valladares B, et al. Selective activity of oleanolic and maslinic acids on the amastigote form of Leishmania spp. Iran J Pharm Res 2017;16(3):1190-1193.

[30] Johnson EC, Ilyas M, Sule MI, Eseyin OA, Oladimeji HO, Etim EI, Udobre AS. Antimicrobial activity of compounds isolated from Aspilia africana (Pers.) C.D. Adams (Asteraceae). Afr J Pharmcol Ther 2016;5:149-154.

[31] Connor WE. Importance of n-3 fatty acids in health and disease. Am J Clin Nutr 2000;71(1 Suppl):171S-175S. doi:10.1093/ajcn/71.1.171S

[32] Simpoulos AP. The importance of the ratio of omega-6/omega-3 essentialfatty acids. Biomed Pharmacother 2002;56(8):365-379. doi:10.1016/S0753-3322(02)00253-6. 